Folia Cardiologica 2017

\title{
Telemonitoring pacjentów z niewydolnością serca Doświadczenia oddziału kardiologii uzyskane podczas realizacji projektu MONITEL-HF
}

\author{
Telemonitoring in patients with heart failure \\ Experience of cardiology department during MONITEL-HF project
}

\author{
Aleksander Płaczek ${ }^{1}$, Marcin Jerzy Wilczek ${ }^{1}$, Elżbieta Gadula-Gacek ${ }^{2}$, Mateusz Tajstra ${ }^{2}$ \\ ${ }^{1}$ WASKO S.A. W Gliwicach \\ ${ }^{2}$ III Katedra i Oddział Kliniczny Kardiologii, Śląskie Centrum Chorób Serca, M. Curie-Skłodowskiej w Zabrzu
}

\section{Streszczenie}

W niniejszej publikacji autorzy przedstawiają rozwiązanie polegające na zastosowaniu znanych i sprawdzonych metod organizacyjnych i technicznych z dziedziny technologii informacyjnych w nowym obszarze usług jakim jest monitorowanie telemedyczne pacjentów z niewydolnością serca, na przykładzie projektu badawczo-rozwojowego MONITEL-HF współfinansowanego przez Narodowe Centrum Badań i Rozwoju w ramach programu STRATEGMED. Dynamiczny rozwój nowoczesnych wyrobów medycznych ze zintegrowaną elektroniką ratującą życie spowodował, że coraz większa ilość danych diagnostycznych może być wysyłana w krótkim czasie do ośrodków medycznych. Decyzje jakie mogą zostać podjęte na ich podstawie zależą od jakości i szybkości ich przetworzenia do postaci informacji akceptowalnej przez personel medyczny oraz od stopnia przygotowania organizacji do procesu ich analizy. W ramach projektu MONITEL-HF wykorzystano elementy kodeksu postępowania Information Technology Infrastructure Library (ITIL) dla działów informatyki. Kodeks ITIL stanowi najbardziej rozpowszechniony zbiór dobrych praktyk stosowany w wielu przedsiębiorstwach i organizacjach rządowych w celu właściwego zarządzania usługami IT zapewniającymi wsparcie najważniejszych procesów biznesowych. Jako usługę biznesową zdefiniowano zdalną opiekę nad pacjentem, która wspierana jest przez procesy realizowane z wykorzystaniem zasobów teleinformatycznych i wyrobów medycznych wszczepianych pacjentowi. Opracowano aplikację, dla której podstawowym założeniem przy jej implementacji była zasada minimalizmu w podejściu do przekazu, rozumiana jako umiejętność eliminacji źródeł bezużytecznej informacji. Gromadzone i przetwarzane sa jedynie te dane, które są potrzebne do wykonania pracy przez wskazaną osobę lub które mogą mieć wpływ na poprawę jakości życia monitorowanego pacjenta (np. aktywność pacjenta stanowiąca dobry wskaźnik jego samopoczucia). Selekcja ta pozwoliła na zmniejszenie obciążenia lekarzy, przekierowanie większości czynności na liczniejszy personel pielęgniarski oraz skupienie się na najpilniejszych przypadkach. Uzyskano zwiększenie produktywności oraz zbudowano podstawy pod zapewnienie jak najlepszych relacji z pacjentem, niezależnie od historii wszczepień stymulatorów, kardiowerterówdefibrylatorów czy urządzeń resynchronizujących. Kardiologia jest jedną z nielicznych dziedzin ochrony zdrowia, gdzie personel medyczny może rozpoczać interwencję medyczną u chorego, który może nie być świadom zagrożenia. Skupienie się przede wszystkim na naprawdę istotnych informacjach jest niezwykle ważne, w sytuacji gdy dane medyczne zaczynają powoli spełniać definicję wielkich zbiorów danych czyli big data.

Słowa kluczowe: selekcja, ITIL, wnioskowanie, analiza, telemedycyna

Folia Cardiologica 2017; 12, 5: 502-509 


\section{Wstęp}

Podstawowym zadaniem każdej jednostki medycznej jest świadczenie usług w zakresie opieki medycznej. W realizacji tego celu w coraz większym stopniu pomagają systemy teleinformatyczne umożliwiające gromadzenie, prezentowanie i analizowanie danych związanych z ruchem chorych. Jednak w 90\% przypadków wdrożone systemy wspierają jedynie procesy diagnostyczno-terapeutyczne jakie są prowadzone w ramach codziennej pracy jednostek medycznych. Wiele problemów z obsługą systemu wynika z faktu, że został on zaprojektowany głównie do zarządzania ruchem chorych, a jest wykorzystywany między innymi do gromadzenia danych niezbędnych do rozliczania usług.

Z kolei wdrażane są rozwiązania mające na celu wspieranie poszczególnych aktywności w ramach wybranego procesu, na przykład ocenę zmian w obrazowaniu wielomodalnym. Jednak kierowane one są głównie do wąskiego grona specjalistów odpowiadających na zapytania lekarzy. Systemy te praktycznie wcale nie wspieraja procesu monitorowania pacjenta, gdy pozostaje on poza siedzibą jednostki medycznej. W ostatnich latach obserwuje się znaczny wzrost ilości tak zwanych urządzeń telemedycznych, które jako wyroby medyczne są w stanie dostarczać informacji diagnostycznych. Dotyczy to szczególnie kardiologii, gdzie innowacyjne rozwiązania stosowane w urządzeniach wszczepialnych (firm Medtronic, Biotronik, Boston Scientific czy St. Jude Medical) pozwoliły na wprowadzenie kompletnie nowych usług. Wzrost popularności tak zwanego home monitoringu, który polega na ciągłym monitorowaniu pacjenta przez odpowiednie urządzenie, wpływa z jednej strony na zmniejszenie czasochłonności i kosztów prowadzenia i leczenia pacjentów z chorobami serca, ale z drugiej strony powoduje zwiększenie ilości informacji, którą lekarze muszą przetworzyć w celu sprawdzenia, czy proces leczenia pacjenta przebiega prawidłowo. Poprawne i niezwłoczne przetwarzanie tych danych jest gwarantem bezpieczeństwa pacjenta. Zbyt późne zdiagnozowanie problemu może kosztować go utratę zdrowia lub życia. Przewiduje się, że coraz częściej podstawowym zadaniem większości jednostek medycznych, szczególnie tych referencyjnych, będzie zdalne monitorowanie pacjentów i świadczenie usługi zdalnej oceny i kwalifikacji ich stanu zdrowia. Potwierdzenie tej tezy znajduje się już w zawartym konsensusie ekspertów z 2015 roku, dotyczącym zaleceń włączania zdalnego monitorowania do opieki nad pacjentem [1]. Rozwiązań tego typu jest tyle, ilu producentów wyrobów medycznych, a sposób realizacji zakupów za pomocą zamówień publicznych powoduje, że w jednej jednostce medycznej wykorzystywane są wszystkie typy, przy czym towarzyszące im rozwiązania informatyczne nie pozwalają na uzyskanie wskazanych w artykule korzyści i zapewnienie odpowiedniej jakości usług. Systemy te są miejscem gromadzenia danych i nie są projektowane pod kątem minimalizacji czasu poświęconego na właściwą diagnozę stanu pacjenta.

\section{Materiał i metody}

Zagadnienie monitorowania pacjenta nie jest zjawiskiem nowym, ale nikt dotychczas nie zajmował się nim z perspektywy lekarza mającego w określonym reżimie czasowym przeprowadzić sprawne monitorowanie leczenia. Wyroby medyczne służące do gromadzenia, wstępnego przetwarzania oraz do mniej lub bardziej zaawansowanej analityki są produkowane jako rozwiązania mające pomóc przede wszystkim pacjentowi. Producenci produkują i wdrażają rozwiązania niezależnie od siebie. Każde z tych urządzeń ma na celu chronić chorego przed skutkami zaburzeń rytmu przez wykonywanie defibrylacji. To jest ich zasadnicze zadanie. Dodatkowo gromadzą znaczne ilości danych, które w następnym etapie należy przetworzyć w użyteczne informacje, mogące stanowić istotne wsparcie dla lekarza. W ramach całego projektu MONITEL-HF zespół badawczy zderzył się z znaczną liczbą modeli urządzeń transmitujących dane do 4 różnych systemów prezentujące zestawienia: CareLink ${ }^{\circledR}$ (Medtronic), Home Monitoring ${ }^{\circledR}$ (Biotronik), Merlin.net ${ }^{\circledR}$ (St.Jude Medical), LATITUDETM Home Monitoring System (Boston Scientific). W ramach głównych grup urządzeń można wyłonić jeszcze podgrupy związane z typem urządzenia: kardiowerter-defibrylator serca (ICD, implantable cardioverter-defibrillator), defibrylator resynchronizujący (CRT-D, cardiac resynchronization therapy defibrillator), stymulator resynchronizujący (CRT-P, cardiac resynchronization therapy pacemaker). Typy urządzeń są jeszcze podzielone na modele. Do procesu monitorowania pacjentów lekarz musi zatem wykorzystać 4 systemy zbierania i prezentowania danych, 72 modele urządzeń (w 3 głównych grupach). Każdy producent posiada własny system prezentujący te dane. Systemy te różnią się zakresem prezentowanej informacji, formą tej prezentacji oraz funkcjonalnością wspomagającą przetwarzanie tych danych. Informacje są przetwarzane i prezentowane w systemach producentów w postaci podsumowań transmisji. Obecnie każdy z systemów jest niezależną aplikacją komputerową o indywidualnych funkcjonalnościach, dostępną poprzez przeglądarkę internetową. Monitorowanie pacjentów wymaga poświęcenia czasu na przeglądanie komunikatów z różnych okresów i typów urządzeń, bez powiązania z obrazem klinicznym zapisanym w odrębnych bazach systemów szpitalnych. Urządzenia wszczepialne wystarczają pacjentowi na określony z góry czas, ze względu na wbudowaną niewymienialną baterię. Wymiana urządzenia to nierzadko wszczepienie innego modelu lub urządzenia innego producenta. Od tego momentu jego dane prezentowane są w innym systemie, a dotychczasowa historia choroby ulega kasacji. 
Wszyscy producenci implementują podstawy standard IEE 11073-10103 (nomenklatura specyficzna dla urządzeń wszczepialnych) oraz starają się być zgodni z profilem IHE IDCO (zakres informacji), ale jednocześnie każdy z nich wprowadza własne rozszerzenia oraz formy publikacji informacji. Oznacza to, że w ramach każdego systemu informatycznego lekarz spotyka się z innym zakresem informacyjnym i innym formatem danych. Większość danych występuje w formie tabel i rysunków zawartych w plikach PDF. Wręcz niemożliwe jest zastosowanie w nich postępowania proceduralnego, co powoduje znacznie wydłużenie procedury obsługi urządzenia.

Codzienna praca personelu medycznego w dużych ośrodkach kardiologicznych wymaga zatem przełączania się między czterema systemami dostawców urządzeń, poszukiwania dodatkowych informacji w repozytoriach lokalnych oraz prowadzenia skomplikowanej wewnętrznej komunikacji między personelem pielęgniarskim i lekarskim. Jeżeli na to nałoży się systematycznie spadającą liczebność lekarzy i pielęgniarek, skokowy wzrost liczby osób posiadających wszczepione urządzenia ratujące życie oraz coraz bardziej skomplikowane choroby współtowarzyszące, to okazuje się, że ilość informacji przesyłanych przez urządzenia jest tak duża, że właściwa reakcja w odpowiednim czasie jest mocno utrudniona, a zapoznanie się ze wszystkimi raportami wręcz niemożliwe. Trzeba pamiętać, że liczba wszczepianych urządzeń wysokoenergetycznych stale rośnie, a w związku z tym ilość danych telemedycznych będzie coraz większa.

W ramach projektu MONITEL-HF przeprowadzono randomizowane badanie REmote SUpervision to Decrease HospitaLization RaTe (RESULT), którym objęto 600 chorych [2]. Jego celem było sprawdzenie, czy stosowanie ciągłego monitorowania pacjentów (300 chorych) na podstawie paczek danych wysyłanych przez wszczepialne urządzenia medyczne pozwala na osiągnięcie lepszych rezultatów terapeutycznych niż w przypadku okresowych wizyt kontrolnych (300 chorych). Dodatkowym celem było określenie kosztów telemonitoringu. Skutki finansowe zastosowania tego typu rozwiązań oraz wpływ monitorowania na jakość życia i rokowanie chorych omówiono w kilku pracach, ale dotychczasowe wyniki nie są jednoznaczne [3-5]. Nie podejmowano zagadnień organizacji procesu monitorowania pacjentów, oceny parametrów w kontekście obrazu klinicznego pacjenta oraz monitorowania pacjentów z urządzeniami wielu producentów. Nie zwracano uwagi na konieczność zmian w organizacji pracy lekarzy wynikającej z wprowadzenia środowiska sterowanego zdarzeniami. W trakcie realizacji badania MONITEL-HF postawiono trzy pytania:

Czy możliwe jest wdrożenie jednolitej strategii monitorowania niezależnie od rodzaju wszczepionego urządzenia?
Czy istnieje sposób, by ciągle wzrastającą ilość informacji przetworzyć w skończonym czasie, tak by wszystkie istotne przypadki zostały obsłużone w zakładanym reżimie czasowym i jakościowym?

Czy zdalny dostęp do danych diagnostycznych nie stanie się nazbyt uciążliwy dla współczesnej kardiologii i czy nie spowoduje to fali oskarżeń pacjentów o zaniechanie postępowania, mimo posiadania dostępu do danych?

\section{Proponowane rozwiązania}

W ramach prowadzonych badań nad problemem optymalizacji działań personelu medycznego oraz sposobem wyboru najważniejszych informacji analizie poddano dane gromadzone z czterech typów urządzeń dostarczanych przez różnych producentów. Przeprowadzono analizę możliwości stworzenia narzędzi kierunkujących działanie personelu medycznego, zgodnie z wymienionymi wcześniej procesami, w celu prawidłowej i terminowej obsługi pacjentów, z jednym podstawowym założeniem: selekcją informacji podawanej na wejście do procesów tak, aby maksymalnie eliminować zajmowanie się zdarzeniami niekrytycznymi (stąd skupienie się autorów na świadomej minimalizacji i klasyfikacji). Z całej biblioteki ITIL zaadaptowano kilka dobrych praktyk, by zapewnić możliwość efektywnego wdrożenia monitorowania niewydolności serca. Uwaga została skupiona przede wszystkim na fazie świadczenia usług (service operation) i jej procesach: zarządzanie zdarzeniami, zarządzanie incydentem oraz zarządzanie problemem. W badanym obszarze procesy te zidentyfikowano jako najbardziej pasujące do zapewnienia codziennych aktywności personelu medycznego odpowiedzialnego za monitorowanie pacjentów. W związku z tym, że urządzenia wysyłają również informacje o swoim statusie to automatycznie w proces identyfikacji włączono również procesy związane z zarządzaniem tak zwaną infrastrukturą techniczną (urządzeniami). Postanowiono wykonać mapowanie między czynnościami koniecznymi do wykonania przez personel medyczny w trakcie analizy danych a definicjami zawartymi w koncepcji ITIL. W projekcie podjęto zatem następujące kroki:

- na podstawie terminologii medycznej zdefiniowano, co rozumiane jest pod pojęciem „zdarzenie” i jaki wpływ ma to zdarzenie na sposób realizacji dalszej usługi. Zdarzeniem określono: alarm, wystąpienie epizodów, standardowe transmisje komunikatów zgłaszanych przez urządzenia wszczepialne;

- zaprojektowano mechanizm transformacji danych pozyskiwanych z urządzeń do postaci oczekiwanej przez lekarzy, na których przeprowadzono unifikacje (odseparowanie od producenta urządzenia), integrację z systemami szpitalnymi oraz zdefiniowano reguły klasyfikacji;

- na podstawie terminologii medycznej zdefiniowano proces „Zarządzani incydentami”, którego celem jest 


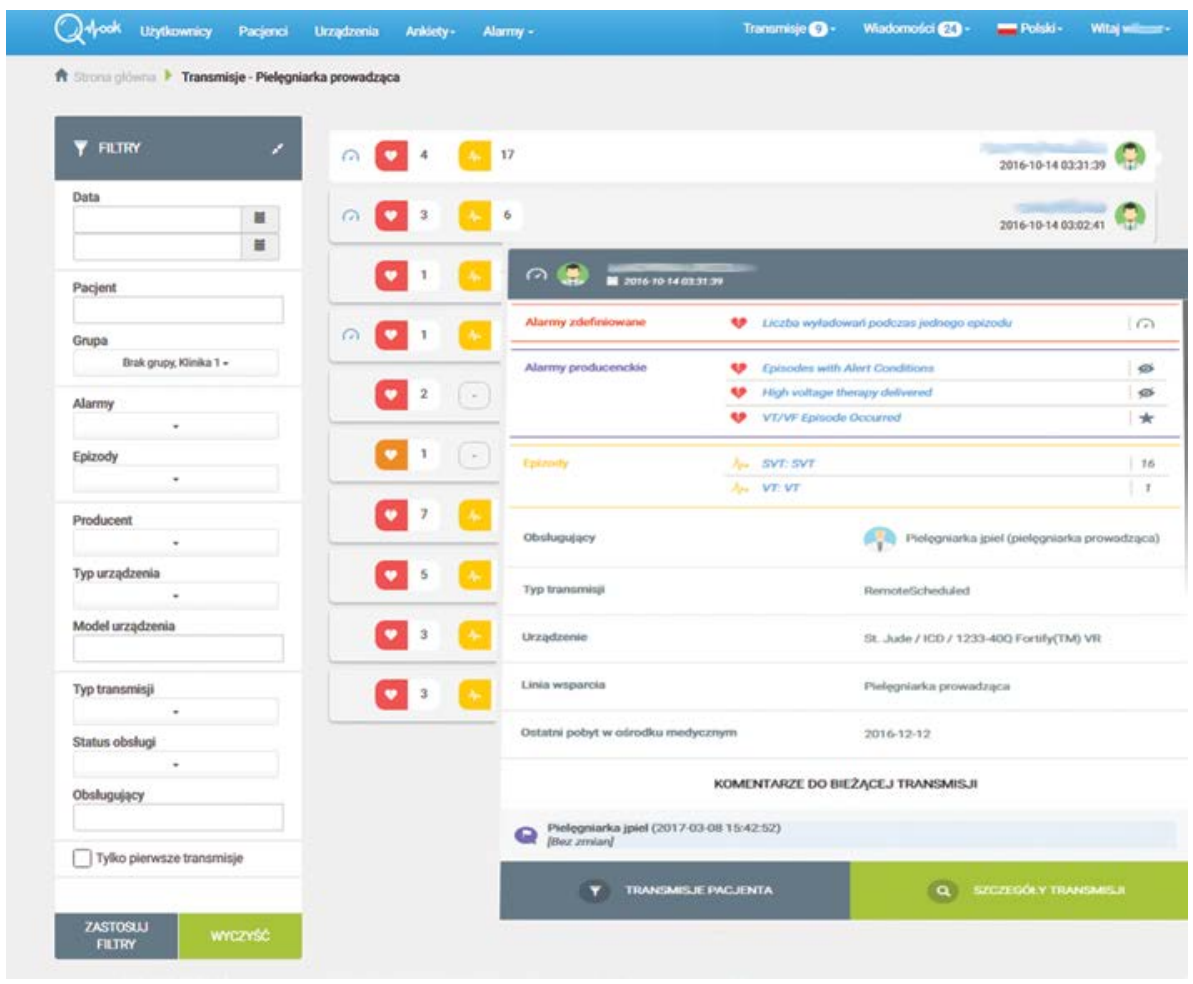

Rycina 1. Prezentacja interfejsu graficznego aplikacji QLook

przywrócenie zdrowia pacjenta do oczekiwanego stanu tak szybko, jak to tylko możliwe lub zapobiegnięcie jego pogorszeniu. Jako „incydent” określono pojedyncze zdarzenie lub serię zdarzeń, które zwiększają niebezpieczeństwo zagrożenia życia i zdrowia pacjenta;

- wprowadzona unifikacja źródeł danych pozwoliła na właściwe zdefiniowania słownika pojęć tak, aby niezależnie od źródła zgłoszenia incydentu był on rozumiany tak samo przez dowolnego lekarza obsługującego system;

- zaprojektowano mechanizm ustalania priorytetów zdarzeń pozwalający na świadome pomijanie mniej znaczących zdarzeń, przekształcanie ich w informację lub zapis dziennika oraz wyzwalanie odpowiednich procedur dla najpilniejszych incydentów;

- opracowano aplikację internetową oraz aplikację mobilną wspierającą monitorowanie pacjenta na podstawie zdarzeń generowanych w podsystemie rejestracji transmisji, które to zdarzenia inicjują obsługę incydentów (ryc. 1).

- W ramach aplikacji umożliwiono budowanie „ustandaryzowanych procedur postępowania” wykorzystujących dane pozyskane z urządzeń w celu wydajnego i szybkiego analizowania, przetwarzania i dokumentowania czynności podejmowanych dla rozwiązania incydentów. W aplikacji zaimplementowano większość z kluczowych technik stosowanych do zarządzania incydentami, takich jak:
- identyfikacja i rejestrowane incydentów wraz z odpowiednią ich kategoryzacją oraz uzupełnieniem o dane diagnostyczne;

- nadawanie priorytetów na podstawie predefiniowanych alarmów generowanych w urządzeniach telemedycznych lub definiowanych niezależnie w systemie dla danego pacjenta lub typu urządzenia;

- wstępna diagnoza przyczyn powstania incydentu bazująca na:

- natychmiastowym zestawieniu danych wysyłanych z urządzenia,

- analizie tendencji na podstawie danych historycznych,

- bieżących i archiwalnych danych obrazujących stan kliniczny pacjenta,

- informacji pozyskanych z dedykowanych ankiet i rozmów telefonicznych wykonywanych bezpośrednio z aplikacji mobilnej;

- możliwość prowadzenia pełnej diagnozy, a w razie potrzeby przekazanie obsługi incydentów do coraz bardziej kompetentnego zespołu;

- zamknięcie incydentu polegające na kontrolowanym potwierdzeniu, że zdrowiu i życiu pacjenta, mimo braku możliwości osobistego zbadania, nie grozi niebezpieczeństwo.

Zgodnie z koncepcją ITIL wydzielono również poszczególne linie wsparcia, którym przypisano odpowiednie 
kompetencje oraz odpowiedzialności. Zaprojektowano trzy linie wsparcia (grupy) nakierowane odpowiednio na personel: 1) pielęgniarski, 2) lekarzy i 3) konsylium lekarskie. Do określonego typu incydentu możliwe jest przypisanie sekwencji czynności (tzw. listy kontrolnej) składającej się z kroków, które powinny zostać wykonane w momencie jego wystąpienia. Każdemu incydentowi nadawany jest odpowiedni priorytet na podstawie czasu wystąpienia, obrazu klinicznego pacjenta oraz dodatkowych warunków sprawdzających informacje pochodzące z systemów szpitalnych lub referencyjnych. W zależności od incydentu jest on przekierowany do odpowiedniej linii wsparcia, gdzie przypisany personel zajmuje się wstępną diagnozą przyczyn. Personel nie musi sprawdzać, czy dany pacjent ma na przykład choroby współtowarzyszące, mogące wpływać na odmienny sposób postępowania. Takie warunki mogą zostać wzięte pod uwage już przy definicji alarmu i przy dynamicznej generacji listy kontrolnej. W przypadku gdy wstępna diagnoza jest niewystarczająca i wymaga pogłębienia, występuje możliwość eskalacji incydentu na poziom wyższy, gdzie zostaną podjęte decyzje co do dalszego sposobu postępowania, przy uwzględnieniu wszystkich już wcześniej wykonanych działań. W dowolnym momencie może nastąpić komunikacja bezpośrednia między personelem a pacjentem lub między zespołem interdyscyplinarnym. Incydenty, w przypadku których realizacja poszczególnych kroków została potwierdzona są zamykane, a informacja o nich archiwizowana. Dzięki temu do pracowników przypisanych do drugiej lub trzeciej linii wsparcia trafiają jedynie incydenty wymagające ich kompetencji [2].

\section{Podsumowanie}

Znaczna liczba rutynowych wizyt pacjentów w poradni kardiologicznej nie wymaga interwencji (71-93\%) i ogranicza się do kontroli urządzenia, bez konieczności zmian programowania czy leczenia. Według aktualnych wytycznych, minimalna częstość kontroli wysokoenergetycznych urządzeń wszczepialnych u pacjentów bez włączonego zdalnego monitorowania wynosi 6 miesięcy. Dla chorych monitorowanych zdalnie interwał między wizytami może zostać wydłużony do 12 miesięcy. Jednak kontrole nawet co 3 miesiące u chorych, u których wystąpiły dodatkowe czynniki obciążające lub schorzenia mogą spowodować znaczne opóźnienie czasu reakcji personelu medycznego i wdrożenia adekwatnego leczenia. Ponadto około 1/4 chorych opuszcza rutynowe kontrole już po roku od implantacji urządzenia (dane z badania TRUST); zaś dzięki systemom zdalnego monitorowania można w łatwiejszy sposób nadzorować sprawność urządzenia i występowanie zdarzeń arytmicznych.

Wynikiem obserwacji sposobu pracy lekarzy w trakcie realizacji projektu jest wdrożenie rozwiązania wspierają- cego procesy obsługi zdarzeń medycznych na zasadach niemal identycznych jak obsługa incydentów technicznych w dziale informatyki. Monitorowanie pacjenta od tego momentu nie polega na sprawdzeniu, czy coś złego się z nim nie dzieje, tylko na reagowaniu na sygnały, że dzieje się coś nieoczekiwanego lub niepożądanego. Zatem lekarze nie mają do czynienia z natłokiem danych, z których nie można wyciągnąć żadnej sensownej informacji bez przeglądania całości dokumentacji z kilku systemów, ale z wyselekcjonowaną, zhierarchizowaną informacją uwzględniającą unikalne dane kliniczne pacjenta. Dodatkowo informacja ta jest uzupełniona o instrukcję postępowania, co umożliwia stworzenie jednolitych procedur postępowania dla wszystkich linii wsparcia. Dzięki temu możliwe jest uruchomienie świadczenia usługi dla pacjenta z określonymi z góry warunkami i poziomem, jak przedstawiono na rycinie 2 .

Do tej pory każdy z systemów monitorowania poszczególnych producentów był obsługiwany za pomoca autorskich systemów znacznie różniących się interfejsem użytkownika i liczbą kroków koniecznych do uzyskania danych pozwalających na określenie całościowego obrazu zmiany stanu klinicznego chorych i sprawności implantowanego urządzenia. Konieczność przeszukiwania niezależnych systemów zawierających dane kliniczne chorych sprawiało, że zadanie to było żmudne i długotrwałe. Wielokrotnie alarmy pochodzące z telemonitoringu były obsługiwane poza godzinami pracy i poza ośrodkiem prowadzącym, bez dostępu do systemów zawierających dane kliniczne chorych. W przypadku konieczności wymiany baterii urządzenia lub rozszerzenia układu dane do tej pory gromadzone w systemie producenta były tracone, co przekładało się na znacznie gorszą znajomość stanu klinicznego chorego (np. utrata danych o wcześniejszych arytmiach). Zintegrowana platforma, w sposób jednolity prezentująca dane wiodących producentów urządzeń wszczepialnych, pozwala na kompilację danych pochodzących z urządzeń i systemów szpitalnych niezależnie od miejsca odczytywania raportu. Dzięki zastosowaniu filtrów zdarzeń i ich współwystępowania pozwala wyodrębnić raporty wymagające najbardziej pilnego obsłużenia. Przygotowanie algorytmów postępowania w przypadku wystąpienia konkretnych sytuacji klinicznych pozwala pielęgniarce czy lekarzowi w sposób jednoznaczny określić, jakie kroki powinny zostać przedsięwzięte, co bardzo skraca czas do zastosowania odpowiedniej terapii. Liczba spływających codziennie raportów (w Śląskim Centrum Chorób Serca [SCCS] łącznie 600-800 dziennie od > 3000 monitorowanych chorych, których liczba lawinowo się) oraz ograniczona liczba wyspecjalizowanego personelu obsługującego systemy telemonitorowania (w SCCS są to dwie dedykowane pielęgniarki elektrofizjologiczne oraz wąskie grono lekarzy) powodują, że udogodnienia oraz 


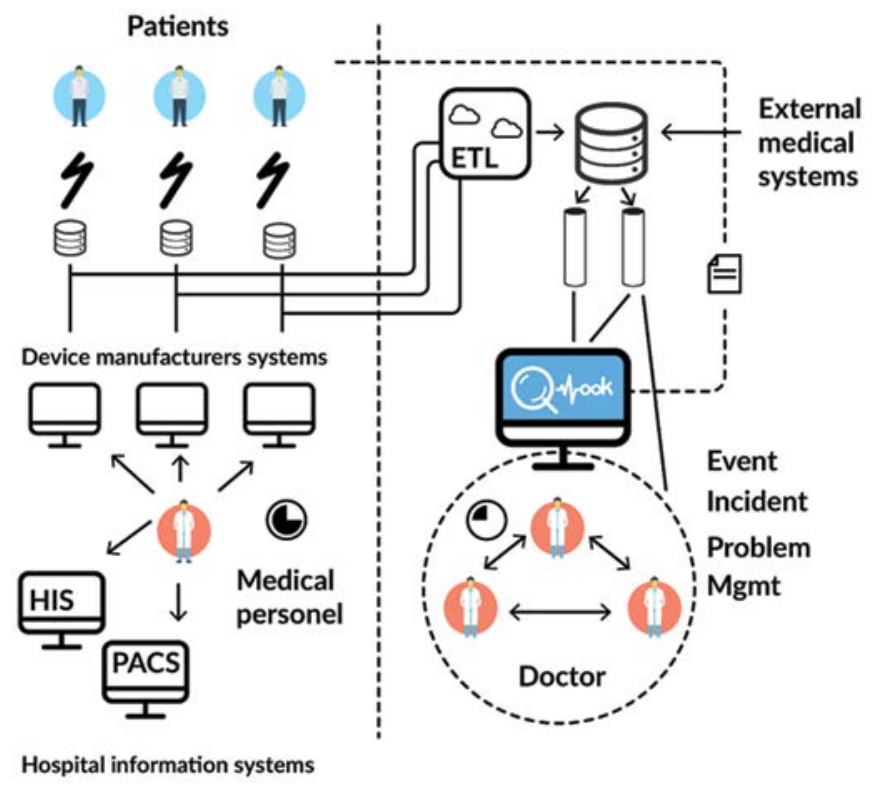

Rycina 2. Zmiana sposobu świadczenia usługi zdalnego monitorowania pacjenta wdrożona w projekcie MONITEL-HF

sposoby przyspieszające obsługę oraz łatwy dostęp do danych klinicznych chorych są niezbędne do zapewnienia płynności działania. Przy obecnych zasobach i korzystaniu z systemów producenckich ocena zawartości wszystkich raportów jest niemożliwa (nie ma nawet możliwości ich całościowego selekcjonowania i ustalania priorytetów), gdyż nawet gdyby przyjąć 24-godzinny tryb pracy (po 12 h/ pielęgniarkę), to na analizę każdego raportu przypadają 2 minuty (!). Nie wliczając $w$ to konieczności przełączeń między systemami oraz przeglądanie dokumentacji medycznej. Dlatego niezwykle przydatna jest funkcja "obserwacji”, pozwalająca wyodrębnić grupy chorych „specjalnej troski”, u których najczęściej dochodzi do zdarzeń niepożądanych. Możliwość wykorzystania atutów tego rodzaju nadzorowania chorych pomaga głównie skrócić czas reakcji w przypadku wystąpienia zdarzeń alarmujących.

\section{Dyskusja}

Czy zatem można odpowiedzieć pozytywnie na postawione wcześniej trzy pytania? Przedstawiony powyżej sposób postępowania, sprawdzony $\mathrm{w}$ trakcie randomizowanego badania, zawiera w sobie pozytywną odpowiedź na pierwsze i drugie pytanie. Odpowiedź na pytanie trzecie jest już dużo trudniejsza. Pojawienie się technologii pozwalających na zdalne monitorowanie i dokonywanie oceny powoduje, że podstawowe założenie, iż lekarz w celu wydania opinii lekarskiej lub podjęcia decyzji terapeutycznej musi mieć bezpośredni kontakt z pacjentem powoli przestaje mieć znaczenie. Nie da się uniknąć rozwoju telemedycyny, ale jej wdrożenie należy przeanalizować pod kątem wad i zalet nie tylko dla pacjenta. Takiego zestawienia dokonano w ramach rejestru doświadczeń projektowych i przedstawiono na rycinie 3. Telemedycyna daje wiele możliwości, ogranicza konieczność osobistych wizyt, ale wymaga właściwej selekcji danych i umiejętności odróżnienia mało istotnych informacji od wartościowych. Wymaga również innej organizacji pracy.

Ilość danych będzie coraz większa. Różnorodność informacji będzie wzrastała wraz z pojawianiem się nowych możliwości rejestracji. Zmienność danych będzie rosła wraz z wprowadzaniem do istniejących wyrobów medycznych nowych funkcjonalności. Zatem dane medyczne będą coraz bardziej wypełniały definicję big data, czyli modelu 3V (volume, velocity, variety), o ile już jej nie spełniają. Big data to zbieranie i analizowanie niejednorodnych źródeł danych o znacznej objętości, szybko zmieniających się i różnorodnych, powiązanych z konkretnym przypadkiem w celu zapewnienia holistycznego obrazu pacjenta i dające możliwość wyznaczenia czynniki mające wpływ na zdrowie pacjenta [6, 7]. Zbiory big data wymagają nieco odmiennej formy przetwarzania w celu wspomagania procesów podejmowania decyzji. Tym bardziej warto jako innowację potraktować sposób wykorzystania możliwości, jakie daje zastosowanie zasad ITIL także w kardiologii.

Analiza dużych badań w dziedzinie zastosowania telemonitoringu w praktyce pokazuje różne wyniki i różne korzyści z zastosowania zdalnej transmisji danych z urządzeń wszczepialnych. Wyniki dwóch przytoczonych poniżej 


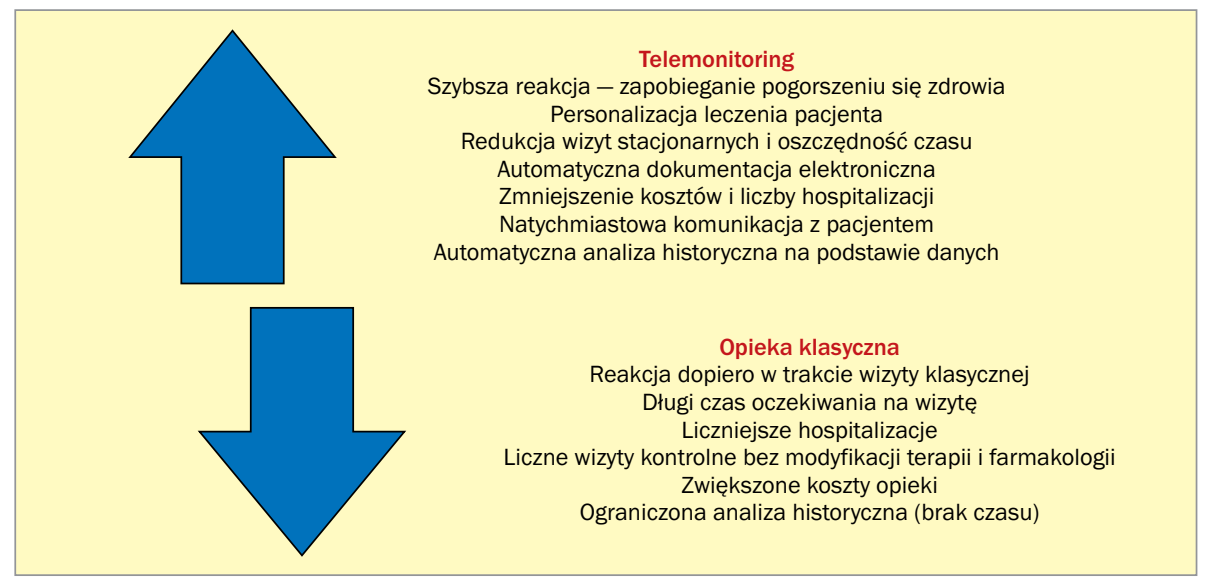

Rycina 3. Wady i zalety telemedycyny

badań wskazują, że monitorowanie pacjentów z pewnością jest bezpieczne i co najmniej równoważne z tradycyjnym zbieraniem danych z urządzeń. W badaniu IN-TIME (Home Monitoring and Heart Failure: The In-Time Trial) w obserwacji rocznej wykazano, że u chorych zdalnie monitorowanych ryzyko zaostrzenia niewydolności serca, poważnych powikłań sercowo-naczyniowych oraz zgonu (randomizacji i prospektywnej obserwacji poddano 664 chorych w średnim wieku $66 \pm 9$ lat, z przewlekłą niewydolnością serca [II i III klasa wg New York Heart Association] i obniżoną frakcją wyrzutową lewej komory $\leq 35 \%$ będzie niższe) [8]. W drugim dużym badaniu Remote Management of Heart Failure Using Implantable Devices (REM-HF) prowadzonym w 9 brytyjskich ośrodkach nie wykazano, by cotygodniowe zdalne monitorowanie pacjentów po wszczepieniu stymulatora przynosiło dodatkowe korzyści w porównaniu z monitorowaniem co kilka miesięcy. Wyniki pierwszego polskiego badania RESULT będą opublikowane dopiero po skończeniu rocznej obserwacji pacjentów (IV kwartał 2017 r.). Autorzy niniejszej pracy mają nadzieję, że będą one miały wkład w światową dyskusję dotyczącą skuteczności stosowania telemonitorowania urządzeń wszczepialnych [9].

\section{Wnioski}

Zastosowanie sprawdzonych standardów i zasad pozwala na uporządkowanie procesu monitorowania pacjentów korzystających z dobrodziejstw telemedycyny i dostosowanie organizacji do reakcji na pojawiające się incydenty. Pozwala również na odciążenie specjalistów oraz zapewnia szybką i kontrolowaną reakcję pielęgniarek. Podsumowując, aby wykorzystać nowe technologie, które zwiększą strumień danych i zachować jednocześnie wysoką jakość usług, należy wdrożyć rozwiązania na bazie znanych i sprawdzonych standardów postępowania, tak jak w przedstawionym przypadku projektu MONITEL-HF. Szczególnie, że w Polsce obowiązują akty prawne, które nakładają na administrację publiczną obowiązek zarządzania incydentami rozumianymi jako minimalizacja prawdopodobieństwa wystąpienia zdarzeń mogących zakłócić podstawowe procesy. W jednostkach medycznych podstawowym procesem jest opieka nad pacjentem, który się zgłosił do niej z problemem zdrowotnym.

\section{Instytucje wspierające}

Narodowe Centrum Badań i Rozwoju. 


\section{Abstract}

In hereby publication the authors shall present the solution encompassing the combination of well-known and verified organisational and technological solutions in the new field of services, namely telemedical monitoring in patients with heart failure, on the example of the research and development project MONITEL-HF co-financed by the National Centre for Research and Development within STRATEGMED Programme. Dynamic development of modern medical devices with integrated electronics saving or supporting life has caused the increase of diagnostic data sent in a specific format and time regime to medical centres for the purpose of their verification. The decisions which may be made on their basis depend on the quality and speed of processing of these data to the form acceptable to the medical personnel as well as on the degree of an organisation preparation for the process of their analysis. MONITEL-HF uses the elements of the Information Technology Infrastructure Library (ITIL) for IT departments. ITIL constitutes the most widespread collection of the best practice applied in many enterprises and governmental organisations for the purpose of appropriate management of IT services. An application was developed, for which the basic premise of its implementation was the principle of minimalism in the approach to communication, understood as the ability to eliminate sources of useless information. Only those data that are needed to perform the work by the person concerned or that may influence the quality of life of the monitored patient (eg patient activity constituting a good indicator of his or her own health) are collected and processed. This selection has made it possible to reduce the burden on physicians, redirect the majority of activities to more nursing staff, and focus on the most urgent cases. Productivity has been enhanced and the foundation for providing the best possible relationship with the patient, regardless of the history of pacemaker implantation, cardioverter defibrillators or resynchronizing devices. Cardiology is one of the few areas where healthcare professionals can start medical intervention in a patient who may not be aware of the risk. Focusing on really important information is extremely important when medical data is slowly beginning to meet the definition of Big Data.

Key words: selection, ITIL, conclusion, datamining, analysis, telemedicine

Folia Cardiologica 2017; 12, 5: 502-509

\section{Piśmiennictwo}

1. Wilkoff BL, Fauchier L, Stiles MK, et al. 2015 HRS/EHRA/APHRS/ SOLAECE expert consensus statement on optimal implantable cardioverter-defibrillator programming and testing. J Arrhythm. 2016; 32(1): 1-28, doi: 10.1016/j.joa.2015.12.001, indexed in Pubmed: 26949427.

2. Tajstra M, Sokal A, Gwóźdź A, et al. REmote SUpervision to Decrease HospitaLization RaTe. Unified and integrated platform for data collected from devices manufactured by different companies: Design and rationale of the RESULT study. Ann Noninvasive Electrocardiol. 2017; 22(4), doi: 10.1111/anec.12418, indexed in Pubmed: 28019051.

3. Łuczak M. System Home monitoring ${ }^{\circledR}$ firmy Biotronik - korzyści z telemonitoringu implantowanych elektronicznych kardiourządzeń. 287 Wyzwania współczesności: informacja - wiedza - zarządzanie. Acta Univ Lodz Folia Oeconom. 2013: 67-77.

4. Kurek A, Tajstra M, Gadula-Gacek E, et al. Impact of remote monitoring on long-term prognosis in heart failure patients in a real-world cohort: results from all-comers COMMIT-HF Trial. J Cardiovasc Electrophysiol. 2017; 28(4): 425-431, doi: 10.1111/jce.13174, indexed in Pubmed: 28176442.

5. Buchta P, Tajstra M, Kurek A, et al. Wpływ zdalnego monitorowania pacjentów $z$ implantowanym kardiowerterem-defibrylatorem (ICD) i kardiowerterem-defibrylatorem z opcją resynchronizacji (CRT-D) na koszty leczenia dla systemu opieki zdrowotnej w populacji Śląska: obserwacja 3-letnia. Kardiol Pol. 2017; 75(6): 573-580, doi: 10.5603/ kp.a2017.0019.

6. Shoemaker M, Curtis A, Vangsnes E, et al. Analysis of daily activity data from implanted cardiac defibrillators: The minimum clinically important difference and relationship to mortality/life expectancy. World J Cardiovasc Dis. 2012; 02(03): 129-135, doi: 10.4236/ wjcd.2012.23021.

7. Cowie MR, Bax J, Bruining N, et al. e-Health: a position statement of the European Society of Cardiology. Eur Heart J. 2016; 37(1): 63-66, doi: 10.1093/eurheartj/ehv416, indexed in Pubmed: 26303835.

8. Hindricks G, Taborsky M, Glikson M, et al. IN-TIME study group*. Implant-based multiparameter telemonitoring of patients with heart failure (IN-TIME): a randomised controlled trial. Lancet. 2014; 384(9943): 583-590, doi: 10.1016/S0140-6736(14)61176-4, indexed in Pubmed: 25131977.

9. Morgan JM, Kitt S, Gill J, et al. Remote management of heart failure using implantable electronic devices. Eur Heart J. 2017; 38(30): 2352-2360, doi: 10.1093/eurheartj/ehx227, indexed in Pubmed: 28575235. 